\title{
An empirical study on relationship between intellectual capital and organizational entrepreneurship: A case study of Islamic Azad university of Semnan
}

\author{
Hasan Kia $^{\mathrm{a}^{*}}$, Abolfazl Danaei ${ }^{\mathrm{b}}$ and Mahshad Normohammadi ${ }^{\mathrm{c}}$
}

${ }^{a}$ Department of Industrial management, Semnan Branch, Islamic Azad University, Semnan, Iran

${ }^{b}$ Department of Management, Semnan branch, Islamic Azad university, Semnan, Iran

${ }^{c}$ Department of Management, Semnan university, Semnan, Iran

\section{H R O N I C L E \\ A B S T R A C T}

Article history:

Received January 14, 2013

Received in revised format

18 April 2013

Accepted 20 April 2013

Available online

April 212013

Keywords:

Intellectual capital

Entrepreneurship

\begin{abstract}
This paper presents an empirical study to investigate the relationship between intellectual capital and organizational entrepreneurship. The proposed model of this paper designs a questionnaire and distributes it among some employees of Islamic Azad University of Semnan branch. For the proposed study, organizational entrepreneurship is considered as independent variable and intellectual capital components are considered as dependent variables. The questionnaire consists of 25 questions in eight different categories. In order to validate the overall questionnaire we have used Cronbach alpha where it was 72.9 for intellectual capital and it was 79.2 for Intrapreneurship. The results of testing various hypotheses indicate that there were positive and meaningful relationships between these two components.
\end{abstract}

(C) 2013 Growing Science Ltd. All rights reserved.

\section{Introduction}

Entrepreneurship within existing organizations called as Intrapreneurship is one of the interesting areas of interest among scholars and practitioners for many years. Intrapreneurship can create value added for revitalization and performance of business units, as well as for small and medium-sized firms. The idea consists of four distinct dimensions. First, the new-business-venturing dimension is associated with pursuing and entering new businesses associated with the firm's current products or markets. Second, the innovativeness dimension explains the creation of new products, services, and technologies. Third, the self-renewal dimension suggests the strategy reformulation, reorganization, and organizational change. Finally, the proactiveness dimension represents top management orientation in pursuing enhanced competitiveness and includes initiative and risk-taking (Boisot, 1995; Antoncic, \& Hisrich, 2001; Stewart, 1997). 
Bontis (1998) presented an empirical investigation on the development of various conceptual measures and models regarding intellectual capital (Brooking, 1996) and its effect on business performance. The primary objective of the study was to explore the development of items and to construct through principal components analysis and partial least squares (PLS) (Boisot, 1995). They showed a valid, reliable, significant and substantive causal link between dimensions of intellectual capital and business performance. Their results would help both academics and practitioners more readily understand the components of intellectual capital.

Bontis et al. (2002) considered the relationship between the stocks and flows of learning across levels in an overall organizational learning system. They reported a positive relationship between the stocks of learning at all levels and business performance. Besides, the misalignment of stocks and flows in an overall organizational learning system was negatively associated with business performance.

Chen et al. (2004) designed a measurement model and a qualitative index system of intellectual capital (IC) to provide a good tool for enterprises to manage their IC. They classified IC into human capital, structural capital, innovation capital and customer capital, and thereupon a qualitative index system for these four IC elements was designed through an analysis of their contents. They reported a significant relationship between the scores of the four IC elements of a company and its business performance, which proved the validity and rationality of the IC measurement model and the qualitative index system. They also emphasized that there was a remarkable relationship between the four IC elements (Westphalen, 1999; Fox, 2005; Fletcher \& Watson, 2007; Manzari et al., 2012).

Roos and Roos (1997) reported the results and conclusions from a large study among small and medium sized enterprises in Scandanavia and suggested that the adoption, alongside the Balance Sheet approach, of a 'Profit and Loss' approach could help companies monitor the flows among various kinds of intellectual capital and between intellectual and financial capital.

Sharafi et al. (2012) surveyed the relationship between dimensions of intellectual capital and knowledge creation in the headquarters of National Gas Corporation of Iran in the year 2010. They selected 261 people from the population randomly and reported that all dimensions of intellectual capital had significant impacts on dimensions of knowledge creation, except for the effects of structural capital on knowledge combination as well as relational capital on knowledge internalization.

Salehi Sadaghiani and Jamali (2012) presented an empirical study to measure the impact of intellectual capital in accounting parts of hospitals and reported that when there was a unit increase in either of human, customer, structural or intellectual capital individually, we could expect of an increase of $1.278,1.210,1.415$ and 1.620 units increase in the performance of the university, respectively.

\section{The proposed study}

The proposed study of this paper investigates the relationship between Intrapreneurship and intellectual capital components represented in Fig. 1 as follows,

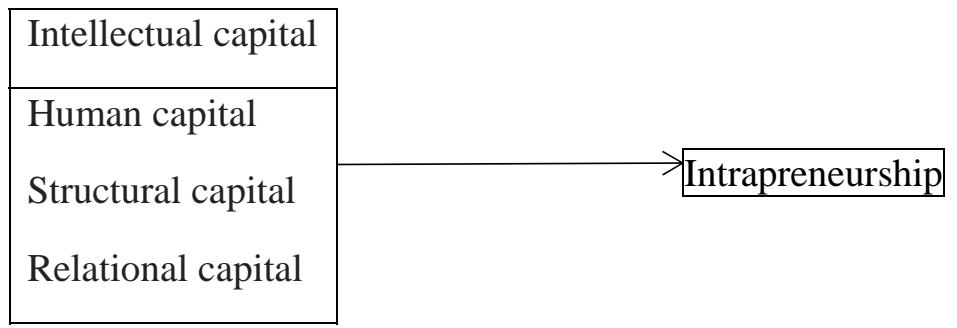

Fig. 1. The framework of the proposed study 
The proposed study of this paper consists of one main hypothesis and three sub-hypotheses as follows,

Main hypothesis: There is a meaningful relationship between Intrapreneurship and intellectual capital.

1. Sub-hypothesis: There is a meaningful relationship between human capital and Intrapreneurship.

2. Sub-hypothesis: There is a meaningful relationship between structural capital and Intrapreneurship.

3. Sub-hypothesis: There is a meaningful relationship between relational capital and Intrapreneurship.

The study was executed among all 97 employees who worked for Islamic Azad university of Semnan branch. In order to measure Intrapreneurship, we used the questionnaire developed by Antoncic and Hisrich (2001) and Fox (2005) also used it in his survey. The questionnaire consists of 25 questions in eight different categories. In order to validate the overall questionnaire we have used Cronbach alpha where it was 72.9 for intellectual capital and it was 79.2 for Intrapreneurship. In order to do detailed calculations, we first need to perform Kolmogorov-Smirnov normality test and Table 1 summarizes the results of our findings,

\section{Table 1}

Kolmogorov-Smirnov normality test

\begin{tabular}{lcc}
\hline & Intrapreneurship & Intellectual capital \\
\hline$Z$ value for K-S & 0.843 & 0.530 \\
P-Value & 0.476 & 0.942 \\
\hline Results & Normal & Normal \\
\hline
\end{tabular}

Based on the results of Table 1, both variables are normally distributed and we can used parametric tests, which are more reliable than non-parametric ones.

\section{The results}

In this section, we present details of our findings on testing the hypotheses of this survey.

\subsection{The main hypothesis: The relationship between Intrapreneurship and intellectual capital}

The main hypothesis of this survey considers the relationship between Intrapreneurship and intellectual capital and the Table 2 summarizes the results of testing the main hypothesis as follows,

Table 2

The results of testing the main hypothesis of the survey

\begin{tabular}{llcc}
\hline & Pearson test & Intrapreneurship & Intellectual capital \\
\hline \multirow{3}{*}{ Intrapreneurship } & Correlation & 1 & 0.483 \\
& Sig. & & 0.000 \\
& Frequency & 97 & 97 \\
\hline \multirow{3}{*}{ Intellectual capital } & Correlation & 0.483 & 1 \\
& Sig. & 0.000 & 97 \\
& Frequency & 97 & 97 \\
\hline
\end{tabular}


As we can observe from the results of Table 2, there is a meaningful and strong relationship between Intrapreneurship and Intellectual capital, which confirms the main hypothesis of this survey.

\subsubsection{The first sub-hypothesis: The relationship between Intrapreneurship and human capital}

The first hypothesis of this survey considers the relationship between Intrapreneurship and human capital and the Table 3 summarizes the results of testing the first hypothesis as follows,

\section{Table 3}

The results of testing the first sub-hypothesis of the survey

\begin{tabular}{llcc}
\hline & Pearson test & Intrapreneurship & Human capital \\
\hline \multirow{3}{*}{ Intrapreneurship } & Correlation & 1 & 0.423 \\
& Sig. & & 0.000 \\
& Frequency & 97 & 97 \\
\hline \multirow{3}{*}{ Human capital } & Correlation & 0.423 & 1 \\
& Sig. & 0.000 & 97 \\
\hline
\end{tabular}

As we can observe from the results of Table 3, there is a meaningful and strong relationship between Intrapreneurship and Human capital, which confirms the first sub-hypothesis of this survey.

\subsubsection{The second sub-hypothesis: The relationship between Intrapreneurship and structural capital}

The second hypothesis of this survey considers the relationship between Intrapreneurship and structural capital and the Table 4 summarizes the results of testing the second sub-hypothesis as follows,

\section{Table 4}

The results of testing the second sub-hypothesis of the survey

\begin{tabular}{llcc}
\hline & Pearson test & Intrapreneurship & Structural capital \\
\hline \multirow{3}{*}{ Intrapreneurship } & Correlation & 1 & 0.465 \\
& Sig. & & 0.000 \\
& Frequency & 97 & 97 \\
\hline \multirow{3}{*}{ Structural capital } & Correlation & 0.465 & 1 \\
& Sig. & 0.000 & 97 \\
\hline
\end{tabular}

As we can observe from the results of Table 4, there is a meaningful and strong relationship between Intrapreneurship and Structural capital, which confirms the second hypothesis of this survey.

\subsubsection{The third sub-hypothesis: The relationship between Intrapreneurship and relational capital}

The third hypothesis of this survey investigates the relationship between Intrapreneurship and relational capital and the Table 5 summarizes the results of testing the third sub-hypothesis. As we can observe from the results of Table 5, there is a meaningful and strong relationship between Intrapreneurship and Relational capital, which confirms the third hypothesis of this survey.

In summary, the main hypothesis as well as three sub-hypotheses of this survey has been confirmed and we can conclude that there are positive and meaningful relationship between intellectual capital and Intrapreneurship. 
Table 5

The results of testing the third sub-hypothesis of the survey

\begin{tabular}{llcc}
\hline & Pearson test & Intrapreneurship & Relational capital \\
\hline \multirow{3}{*}{ Intrapreneurship } & Correlation & 1 & 0.419 \\
& Sig. & & 0.000 \\
& Frequency & 97 & 97 \\
\hline \multirow{3}{*}{ Relational capital } & Correlation & 0.419 & 1 \\
& Sig. & 0.000 & 97 \\
& Frequency & 97 & \\
\hline
\end{tabular}

\section{Conclusion}

In this paper, we have presented an empirical investigation to study the relationship between Intrapreneurship and Relational capital in one of Islamic Azad universities in province of Semnan, Iran. Since there were limited numbers of the employees working for this university we have decided to cover all of them in our survey. The study has adopted a questionnaire from the literature and examined the main hypothesis as well as three sub-hypotheses of the survey based on Pearson correlation ratios. The survey has confirmed the main and all three sub-hypotheses of the survey.

\section{Acknowledgment}

The authors would like to thank the anonymous referees for constructive comments on earlier version of this work, which has contributed to the quality of the paper. We would like to also thank the officials of Islamic Azad University of Semnan for their support on accomplishment of this survey.

\section{References}

Antoncic, B., \& Hisrich, R. D. (2001). Intrapreneurship: Construct refinement and cross-cultural validation. Journal of business venturing, 16(5), 495-527.

Boisot, M. (1995). Information space: A framework for learning in organizations, institutions and culture. Cengage Learning Business Pr.

Bontis, N. (1996). There's a price on your head: managing intellectual capital strategically. Business Quarterly, 60, 40-78.

Bontis, N. (1998). Intellectual capital: an exploratory study that develops measures and models. Management decision, 36(2), 63-76.

Bontis, N., Crossan, M. M., \& Hulland, J. (2002). Managing an organizational learning system by aligning stocks and flows. Journal of management studies, 39(4), 437-469.

Brooking, A. (1996). Intellectual Capital. International Thompson Business Press, London.

Chen, J., Zhu, Z., \& Xie, H. Y. (2004). Measuring intellectual capital: a new model and empirical study. Journal of Intellectual capital, 5(1), 195-212.

Fletcher, D. E., \& Watson, T. J. (2007). Entrepreneurship, management learning and negotiated narratives: 'Making it otherwise for us - otherwise for them'. Management Learning, 38(1), 9-26.

Fox, J. M. (2005). Organizational Entrepreneurship and the organizational performance linkage in university extension. Doctoral dissertation, Ohio state university.

Manzari, M., Kazemi, M., Nazemi, S., \& Pooya, A. (2012). Intellectual capital: Concepts, components and indicators: A literature review. Management Science Letters, 2(7), 2255-2270.

Roos, G., \& Roos, J. (1997). Measuring your company's intellectual performance. Long range planning, 30(3), 413-426.

Salehi Sadaghiani, J., \& Jamali, H. (2012). An empirical study the relationship between intellectual intelligence and university performance. Management Science Letters, 2(5), 1543-1548. 
1344

Sharafi, M., Mohammadi moghadam, Y., \& Sharafi, T. (2012). The relationship between dimensions of intellectual capital and knowledge creation: Case Study of the headquarters of national gas corporation of Iran. Management Science Letters, 2(1), 147-160.

Stewart, T. A. (1997). Intellectual capital: The new wealth of nations. New York.

Westphalen, S. (1999). Reporting on human capital: objectives and trends. In OECD International Symposium Measuring and Reporting Intellectual Capital, Technical Meeting (pp. 9-10). 